\title{
Impact of genetic merit for milk somatic cell score of sires and maternal grandsires on herd life of their daughters
}

\author{
R. H. Miller, ${ }^{1}$ H. D. Norman, J. R. Wright, and J. B. Cole \\ Animal Improvement Programs Laboratory, ARS, USDA, Beltsville, MD 20705-2350
}

\section{ABSTRACT}

A retrospective study of the impact of the estimated breeding values of sires and maternal grandsires for somatic cell score (SCS) on productive life (PL) of Holsteins and Jerseys was conducted. Data included records from 2,626,425 Holstein and 142,725 Jersey cows. The sires and maternal grandsires of cows were required to have been available through artificial insemination and to have predicted transmitting ability (PTA) SCS evaluations based on 35 or more daughters. A weighted function (WPTA) of sire and maternal grandsire PTA for SCS was used: (sire PTA + 0.5 maternal grandsire PTA)/1.5. The 3 dependent variables were PL, frequency of cows culled for mastitis, and first-lactation SCS. The model included effects of herd, birth year, and WPTA (WPTA was categorized into groups: $<2.70,2.70$ to $2.79, \ldots, 3.20$ to 3.29 , $\geq 3.30$ ). For analysis of first-lactation SCS, calving year and calving month were substituted for birth year. Differences among WPTA groups were highly significant: as WPTA increased, PL decreased, whereas percentage culled for mastitis and first-lactation SCS increased. The range in PL from lowest to highest WPTA was 5.07 mo for Holsteins and 4.73 mo for Jerseys. Corresponding differences for percentage culled for mastitis were 7.0 and $5.6 \%$ and for SCS were 0.95 and 1.04 (for Holsteins and Jerseys, respectively). Although phenotypic studies suggest that cows with extremely low SCS were less resistant to mastitis, our results showed consistent improvements in PL, percentage culled for mastitis, and SCS of daughters when bulls were chosen for low PTA SCS.

Key words: selection, mastitis, culling

\section{INTRODUCTION}

Somatic cell count is a commonly accepted measure of milk quality. Milk of individual cows from herds enrolled in DHIA testing plans are often tested monthly

Received August 25, 2008.

Accepted January 6, 2009.

${ }^{1}$ Corresponding author: millerrh@juno.com for SCC, largely because elevated SCC reflects the presence of clinical and subclinical mastitis. Dairy personnel are encouraged to maintain a low herd average SCC, and are frequently rewarded with higher milk prices for doing so. Beginning in 1994, genetic evaluations were provided for SCS, a logarithmic function of SCC (Schutz, 1994). Schutz (1994) cited estimates of the heritability of SCS ranging from 0.05 to 0.27 .

Phenotypic studies, however, have suggested that cows with very low SCC are subsequently more likely to become infected. Schukken et al. (1999) found that cows with a higher prechallenge SCC had a decreased risk of subsequent infection. In a study of 1 low-SCC herd, Suriyasathaporn et al. (2000) reported that a low SCC was associated with an increased risk of a cow subsequently having clinical mastitis.

It has been suggested that an initial low SCC may reflect a somewhat lower immune efficiency in the mammary gland. Beaudeau et al. (2002) studied the relationship between SCC and subsequent incidence of clinical mastitis in 121 French herds. They concluded that herds with a high proportion of cows with low SCC were at increased risk of subsequent clinical mastitis. However, Rupp et al. (2000) found results contrary to those of Schukken et al. (1999) and Suriyasathaporn et al. (2000) in a study of 1,254 French herds. Cows with the lowest mean SCC in their first lactation had the lowest risk of clinical mastitis in their second lactation. Contrary results were also found by Canadian researchers (Sewalem et al., 2006), who reported that cows with SCS above the breed average had a greater risk of being culled for all reasons than cows with a below breed average SCS. Favorable results of genetic selection to reduce the incidence of mastitis were reported by Heringstad et al. (2004).

The suggestion that extremely low SCC may lead to reduced resistance to mastitis infections brings into question whether long-term genetic selection for lower SCC might eventually have undesirable effects (i.e., effects of selection may not be linear). Information is needed to clarify whether consistent selection for low SCS produces the expected benefits of reducing the frequency of mastitis infections. Our objective was to determine how SCS evaluations of bulls across 2 genera- 
tions would affect the productive life $(\mathbf{P L})$, frequency of culling for mastitis, and the first-lactation SCS of their daughters.

\section{MATERIALS AND METHODS}

Lactations of Holstein and Jersey cows born from January 1, 1993, to December 31, 1999, and with calving dates from January 1, 1995, to December 31, 2005, were extracted from the national dairy database at the Animal Improvement Programs Laboratory (AIPL), ARS, USDA (Beltsville, MD). Sires and maternal grandsires (MGS) of these cows were required to have been available through AI and to have PTA SCS evaluations based on 35 or more daughters. Cows that changed herds or that had unreported lactations through their first 5 lactations were excluded, as were cows from herds with $<10$ cows. These restrictions yielded data from 2,626,425 Holstein cows (21,857 sires) from 33,102 herds and from 142,725 Jersey cows (1,440 sires) from 3,837 herds. The August 2007 AIPL PL phenotypic records of cows were obtained (VanRaden and Wiggans, 2003). The time period selected for this study allowed ample time for cows born before 2000 to calve and express PL. For cows still in the herd, the latest estimate of PL was used.

Three analyses were performed: 1 with the most recent PL estimate of cows, 1 with the frequency of cows culled for mastitis (i.e., dependent variable $=0$ if a cow was never culled for mastitis, and 1 if a cow was culled for mastitis), and 1 with the first-lactation mature-equivalent SCS of the daughter (Schutz et al., 1995) as dependent variables. For each cow, a weighted function of sire and MGS SCS PTA (WPTA) was computed: (Sire PTA + 0.5 MGS PTA)/1.5. The models were fitted using PROC GLM (SAS Institute, 2000) and included the effects of herd, WPTA, and birth year of the cow; in the model for mature-equivalent SCS, calving year and calving month were included instead of birth year. Categories for WPTA were $<2.70,2.70$ to $2.79, \ldots, 3.20$ to 3.29 , and $\geq 3.30$. A supplementary analysis tested the linearity of the regression of the 3 dependent variables on WPTA.

\section{RESULTS AND DISCUSSION}

Mean cow PL was 27.1 mo for Holsteins and 35.9 for Jerseys. This range in PL was 0 to 193 mo for Jerseys and 0.14 to 163 mo for Holsteins. Mean percentage of cows culled for mastitis was $10.0 \%$ for Holsteins and $10.3 \%$ for Jerseys. Mean mature-equivalent first-lactation SCS was 3.09 for Holsteins and 3.34 for Jerseys. The range in first-lactation mature-equivalent SCS was 0.0 to 11.7 for Holsteins and 0.0 to 10.8 for Jerseys. Mean PTA
SCS for sires and MGS were 3.00 and 2.98 (Holsteins) and 3.02 and 2.99 for Jerseys (the base for SCS for each breed was set at 3.0, not at breed average). Figure 1 shows the distribution of PTA SCS for the 2 breeds; in both breeds, $42 \%$ of sires had PTA SCS $<3.0$.

Table 1 shows the number of daughters with both sire and MGS SCS included in the analysis of SCS (numbers for Holsteins were slightly less for analyses of PL and slightly larger for percentage of culling because of mastitis). The frequency of cows in the low-WPTA groups was small, but should be sufficient to project effects of extreme selection.

Because no experiments practicing selection on SCS have been published, our analyses looked retrospectively at actual matings to estimate effects of selection. Differences in PL associated with WPTA are shown in Table 2. Differences were highly significant $(P<$ 0.0001). As WPTA increased, daughter PL decreased, although decreases in PL for Holsteins were less at larger levels of WPTA than at smaller levels. The range in PL from lowest to highest WPTA was similar for the 2 breeds, 5.07 mo for Jerseys and 4.73 mo for Holsteins. Because each month of additional PL is valued at $\$ 29$ in the current USDA lifetime net merit index, a 200cow Holstein herd using sires and MGS with the lowest WPTA grouping should be worth nearly $\$ 10,000$ more than a similarly sized herd using sires and MGS with the greatest WPTA group (assuming an average of 2.8 lactations per cow). This calculation does not consider other expenses associated with elevated SCS, such as lost premiums for low-SCC milk, increased expenses to treat infections, and milk discarded because of mastitis treatment. Such extreme selection is, of course, unlikely in practice. Reports of genetic change for SCS of Holstein cows indicated an unfavorable increase before 2000, but a favorable decline after 2000 (Animal Improvement Programs Laboratory, 2008). The earlier unfavorable change in breeding value for SCS likely was

Table 1. Distribution of number of daughters by a weighted average of PTA SCS ${ }^{1}$ of sires and maternal grandsires

\begin{tabular}{lrr}
\hline Weighted PTA SCS & Jersey $^{2}$ & Holstein $^{3}$ \\
\hline$<2.70$ & 1,042 & 22,636 \\
2.70 to 2.79 & 5,694 & 160,183 \\
2.80 to 2.89 & 20,339 & 500,656 \\
2.90 to 2.99 & 38,700 & 722,822 \\
3.00 to 3.09 & 41,604 & 644,019 \\
3.10 to 3.19 & 25,503 & 373,063 \\
3.20 to 3.29 & 8,854 & 141,231 \\
$\geq 3.30$ & 984 & 61,815 \\
\hline
\end{tabular}

${ }^{1}($ Sire PTA + 0.5 maternal grandsire PTA $) / 1.5$.

${ }^{2} 1,440$ bulls.

${ }^{3} 21,857$ bulls. 
Table 2. Least squares mean differences in daughter productive life (PL) among levels of weighted average PTA SCS ${ }^{1}$ relative to the $\geq 3.30$ group

\begin{tabular}{lcc}
\hline & \multicolumn{2}{c}{ PL difference, mo } \\
\cline { 2 - 3 } Weighted PTA SCS & Jersey $^{2}$ & Holstein $^{3}$ \\
\hline$<2.70$ & 5.07 & 4.73 \\
2.70 to 2.79 & 3.88 & 3.74 \\
2.80 to 2.89 & 2.99 & 3.08 \\
2.90 to 2.99 & 2.88 & 2.47 \\
3.00 to 3.09 & 2.51 & 1.82 \\
3.10 to 3.19 & 2.17 & 1.23 \\
3.20 to 3.29 & 1.24 & 0.67 \\
$\geq 3.30$ & 0 & 0 \\
\hline
\end{tabular}

${ }^{1}($ Sire PTA +0.5 maternal grandsire PTA $) / 1.5$.

${ }^{2} F$-value $=16.88(P<0.0001) ; \mathrm{n}=139,062$.

${ }^{3} F$-value $=933.9(P<0.0001) ; \mathrm{n}=2,540,602$.

due to the genetic correlation between SCS and milk yield.

Differences in percentage of cows culled for mastitis associated with levels of WPTA are shown in Table 3. Differences were highly significant $(P<0.0001)$. Percentage culled for mastitis generally increased as WPTA increased. The range in percentage culled, from highest to lowest WPTA, was $5.6 \%$ for Jerseys and 7.0\% for Holsteins. The lowest percentage culled was in the 2.70 to 2.79 WPTA group for Jerseys but in the $<2.70$ group for Holsteins. The maximum percentage culled was at the $\geq 3.30$ level for Holsteins, but was at the
Table 3. Least squares mean differences in culling for mastitis among levels of weighted average PTA SCS ${ }^{1}$ relative to the $\geq 3.30$ group

\begin{tabular}{lcc}
\hline & \multicolumn{2}{c}{ Culled for mastitis, $\%$} \\
\cline { 2 - 3 } Weighted PTA SCS & Jersey $^{2}$ & Holstein $^{3}$ \\
\hline$<2.70$ & -2.3 & -7.0 \\
2.70 to 2.79 & -3.6 & -6.4 \\
2.80 to 2.89 & -2.1 & -5.7 \\
2.90 to 2.99 & -1.6 & -4.9 \\
3.00 to 3.09 & -1.1 & -4.0 \\
3.10 to 3.19 & -0.1 & -3.1 \\
3.20 to 3.29 & 2.0 & -2.0 \\
$\geq 3.30$ & 0 & 0 \\
\hline
\end{tabular}

${ }^{1}($ Sire PTA + 0.5 maternal grandsire PTA $) / 1.5$.

${ }^{2} F$-value $=26.5(P<0.0001) ; \mathrm{n}=142,725$.

${ }^{3} F$-value $=693.1(P<0.0001) ; \mathrm{n}=2,551,611$.

3.20 to 3.29 level for Jerseys. The number of cows in the various WPTA categories was much smaller for Jerseys (Table 1). The erratic results for Jerseys for extreme categories are likely due to the small numbers.

Trends in the daughters' own SCS can be considered as simulating a direct response to selection of sires on PTA SCS and should mirror changes in WPTA (Table 4). For Jerseys, the range in daughter matureequivalent SCS from the $<2.70$ WPTA category to the $\geq 3.30$ category was +1.04 . The corresponding range for Holsteins was +0.95 . The average increase in daughter mature-equivalent SCS between successive WPTA

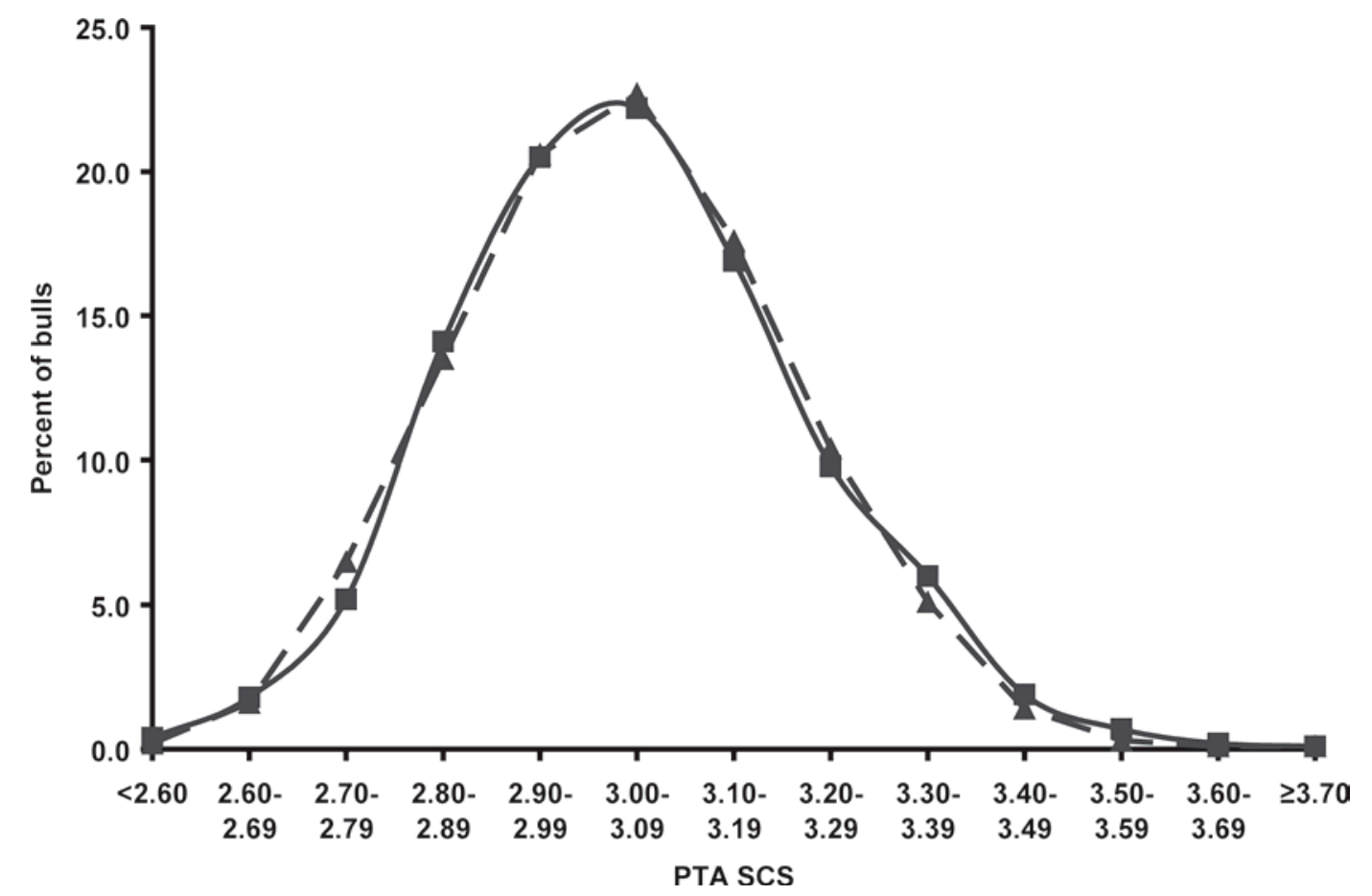

Figure 1. Distribution of PTA SCS for AI sires with at least 70\% reliability and 50 daughters for Holstein (ם) and Jersey (ム). 
Table 4. Least squares mean differences in daughter mature-equivalent SCS among levels of weighted average PTA SCS ${ }^{1}$ in first lactation relative to the $\geq 3.30$ group

\begin{tabular}{|c|c|c|}
\hline \multirow[b]{2}{*}{ Weighted PTA SCS } & \multicolumn{2}{|c|}{ Mature-equivalent SCS } \\
\hline & Jersey $^{2}$ & Holstein $^{3}$ \\
\hline$<2.70$ & -1.04 & -0.95 \\
\hline 2.70 to 2.79 & -0.76 & -0.83 \\
\hline 2.80 to 2.89 & -0.66 & -0.71 \\
\hline 2.90 to 2.99 & -0.53 & -0.58 \\
\hline 3.00 to 3.09 & -0.44 & -0.45 \\
\hline 3.10 to 3.19 & -0.32 & -0.32 \\
\hline 3.20 to 3.29 & -0.19 & -0.18 \\
\hline$\geq 3.30$ & 0 & 0 \\
\hline
\end{tabular}

${ }^{1}($ Sire PTA +0.5 maternal grandsire PTA $) / 1.5$

${ }^{2} F$-value $=273.2(P<0.0001) ; \mathrm{n}=141,925$.

${ }^{3} F$-value $=6432.3(P<0.0001) ; \mathrm{n}=2,626,425$.

levels was 0.15 for Jerseys and 0.14 for Holsteins. The extreme categories had the least numbers of cows and had no limitation on extremes. The Jersey estimates for extreme levels of WPTA were based on fewer cows than those for Holsteins and were more erratic.

Our results indicate that using bulls with lower PTA SCS will produce daughters with lower first-lactation SCS, longer PL, and a lower frequency of culling for mastitis. The sires used in our data were chosen by dairy personnel primarily based on criteria other than PTA SCS (PTA SCS was not yet available at the time of many of these earlier matings and was not widely emphasized throughout the remainder of the period). However, a wide distribution of genetic evaluations for SCS was present, permitting conclusions about results of selecting sires based on their PTA SCS. Our Holstein results showed no diminution of response in SCS of daughters at extremely low levels of PTA SCS. A supplemental analysis fitted regressions of dependent variables on WPTA; there was no deviation from linearity for Jerseys and only a slight deviation for Holsteins (the numbers of Holstein cows were much larger than the numbers of Jerseys).

Previous studies reported that cows with extremely low SCC were subsequently more likely to become infected with clinical mastitis. The protection afforded by increased SCC reported by Linde (1982) and Schukken et al. (1999) was associated with prior udder infections. A similar protective effect was reported for intramammary devices that artificially increased SCC in mammary quarters (Paape et al., 1986). These studies were based on variation in SCC at the phenotypic level. In contrast, our study modeled results of genetic selection for lower SCS and showed benefits expected with reduced frequency of mastitis (lower SCS, longer PL, and reduced culling for mastitis). The response observed showed no attenuation at extreme levels of selection.
Such selection likely increases innate resistance to mastitis. There is clearly an advantage in lowering SCS beyond current levels by genetic means.

Selection of sires with low PTA SCS lengthens PL, reduces mastitis frequency, and probably lowers other costs of the disease. However, these results should not be interpreted as advocating selection exclusively for decreased SCS. The current net merit evaluation (VanRaden, 2004) provides a proper weighting for SCS (correlation of -0.44 with the index). Selection for decreased SCS through use of the current net merit index is expected to produce a reduction in SCS, as well as beneficial changes in several other traits. The genetic improvement in SCS since 2000 indicates that selection is being practiced (Animal Improvement Programs Laboratory, 2008).

\section{CONCLUSIONS}

Studies were conducted on Holsteins and Jerseys to determine the effects of 2 generations of sire selection for decreased SCS of daughters. Cows with a genetic background of low sire and MGS PTA SCS had significantly longer PL, decreased first-lactation SCS, and less culling for mastitis.

\section{ACKNOWLEDGMENTS}

The cooperation of the dairy records processing centers (AgriTech Analytics, Visalia, CA; AgSource Cooperative Services, Verona, WI; DHI Computing Service, Provo, UT; and Dairy Records Management Systems, Raleigh, NC) in supplying lactation yield data are appreciated. The suggestions of 2 anonymous reviewers are appreciated.

\section{REFERENCES}

Animal Improvement Programs Laboratory. 2008. Trend in somatic cell score for Holstein or Red \& White. http://aipl.arsusda.gov/ eval/summary/trend.cfm?R_Menu=HO.s Accessed May 25, 2008.

Beaudeau, F., C. Fourichon, H. Seegers, and N. Bareille. 2002. Risk of clinical mastitis in dairy herds with a high proportion of low individual milk somatic-cell counts. Prev. Vet. Med. 53:43-54.

Heringstad, B., Y. M. Chang, D. Gianola, and G. Klemetsdal. 2004. Multivariate threshold model analysis of clinical mastitis in multiparous Norwegian dairy cattle. J. Dairy Sci. 87:3038-3046.

Linde, C. 1982. The effect of coagulase-negative staphylococci in the cow's udder on experimental induction of mastitis and on milk production. PhD Diss. Univ. Agric. Sci., Uppsala, Sweden.

Paape, M. J., G. Ziv, R. H. Miller, and W. D. Schultze. 1986. Update on the use of intramammary devices in the control of mastitis. Pages 87-103 in Proc. 25th Annu. Mtg. Natl. Mastitis Counc. Natl. Mastitis Counc., Verona, WI.

Rupp, R., F. Beaudeau, and D. Boichard. 2000. Relationship between milk somatic-cell counts in the first lactation and clinical mastitis occurrence in the second lactation of French Holstein cows. Prev. Vet. Med. 46:99-111.

SAS Institute. 2000. SAS/STAT User's Guide. SAS Inst., Cary, NC. 
Schukken, Y. H., K. E. Leslie, D. A. Barnum, B. A. Mallard, J. H. Lumsden, P. C. Dick, G. H. Vessie, and M. E. Kehrli. 1999. Experimental Staphyloccus aureus intramammary challenge in late lactation dairy cows: Quarter and cow effects determining the probability of infection. J. Dairy Sci. 82:2393-2401.

Schutz, M. M. 1994. Genetic evaluation of milk somatic cell count for United States dairy cattle. J. Dairy Sci. 77:2113-2129.

Schutz, M. M., P. M. VanRaden, G. R. Wiggans, and H. D. Norman. 1995. Standardization of lactation means of somatic cell score for calculation of evaluations. J. Dairy Sci. 78:1843-1854.

Sewalem, A., F. Miglior, G. J. Kistenmaker, and B. J. Vandermaal. 2006. Analysis of the relationship between somatic cell score and functional longevity in Canadian dairy cattle. J. Dairy Sci 89:3609-3614.

Suriyasathaporn, W., Y. H. Schukken, M. Nielen, and A. Brand. 2000. Low somatic cell count: A risk factor for subsequent clinical mastitis in a dairy herd. J. Dairy Sci. 83:1248-1255.

VanRaden, P. M. 2004. Invited Review: Selection on net merit to improve lifetime profit. J. Dairy Sci. 87:3125-3131.

VanRaden, P. M., and G. R. Wiggans. 2003. Methods used to compute multi-trait productive life. AIPL Res. Rep. PL2 (11-03). http:// aipl.arsusda.gov/reference/multi-pl.htm Accessed May 19, 2008. 